\title{
The impact of carotid revascularization on cognitive function
}

\author{
O impacto da revascularização carotídea sobre a função cognitiva
}

\author{
Germano da Paz Oliveira', Ana Terezinha Guillaumon², Iran Batista de Brito33, Joana Mayra Teixeira Lima ${ }^{3}$ \\ Sérgio Clementino Benvindo ${ }^{4}$, Fernando Cendes $^{5}$
}

\begin{abstract}
The concept that carotid disease may compromise cognitive function was initially proposed by Fisher in 1951, based on an autopsy case. However, some topics involving cognitive function remain controversial, such as its correlation with carotid obstructive disease. So, the authors of this review evaluate the impact of carotid revascularization on cognitive function and the repercussions of the revascularization technique (carotid stenting vs. endarterectomy) chosen. It was clear from the literature reviewed that carotid stenosis is related to a decline in cognitive function over time. However, controversy still remains over the impact of carotid revascularization on cognitive function. With elation to the technique employed (carotid stenting vs. endarterectomy), the majority of studies found no difference between the two techniques in terms of overall cognitive outcome.
\end{abstract}

Keywords: carotid stenosis; therapy; carotid endarterectomy; cognition.

\begin{abstract}
Resumo
A noção de que a doença carotídea pode comprometer a função cognitiva foi proposta inicialmente por Fisher, em 1951, baseado em um caso de necropsia. Porém, alguns tópicos envolvendo a função cognitiva permanecem controversos, tais como sua correlação com a doença obstrutiva da carótida. Nesse sentido, os autores desta revisão buscam avaliar o impacto da revascularização carotídea e a repercussão da técnica de revascularização empregada (endarterectomia versus angioplastia carotídea) sobre a função cognitiva. A partir da literatura levantada, ficou claro que as estenoses carotídeas estão relacionadas com o declínio cognitivo ao longo do tempo, mas ainda há controvérsia no que se refere ao impacto da revascularização carotídea sobre a função cognitiva. Quanto à técnica empregada (angioplastia versus endarterectomia carotídeas), a maioria dos estudos não demonstrou distinção entre as duas técnicas quanto ao desfecho cognitivo geral.
\end{abstract}

Palavras-chave: Estenose das carótidas; terapia; endarterectomia das carótidas; cognição.

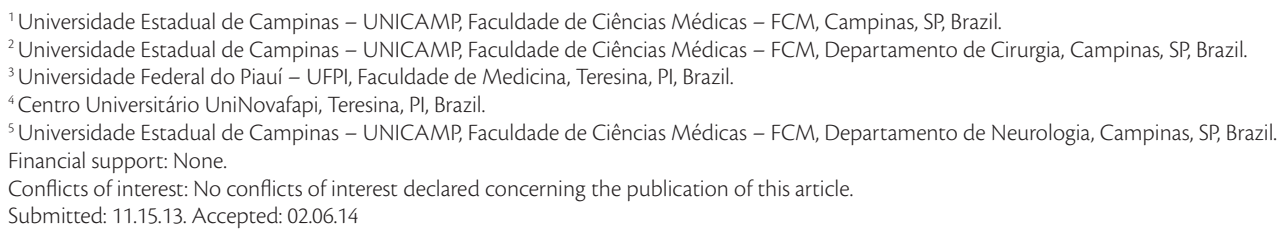




\section{INTRODUCTION}

The concept that carotid disease may compromise cognitive function was initially proposed by Fisher in 1951, based on an autopsy case. ${ }^{1,2}$ He postulated that occlusive carotid disease could provoke a state of dementia and proposed restoration of anterograde flow to reverse the condition. This insight contributed to the first carotid reconstruction $(1951)^{1,3}$ and later to the first carotid endarterectomy (CEA) $)^{1,4,5}$ in patients who had suffered a stroke and had internal carotid stenosis, which introduced CEA as an important option for stroke management. ${ }^{1}$

The term Cognitive Function (CF) is used to describe the way in which a person produces and controls their mental and behavioral processes such as thinking, learning, remembering, solving problems and memorizing. ${ }^{1}$ The basic distinction between cognitive deficit and neurological deficit is that the second relates to a loss of localized sensory or motor function - such as the ability to move a $\operatorname{limb}$ - whereas the first relates to loss of a system, such as the ability to remember new facts. Studies suggest that one in three North Americans experience a stroke, dementia or both at some point during their lives, ${ }^{6,7}$ and that $64 \%$ of individuals who suffer a cerebrovascular event will develop dementia. ${ }^{6,8}$ Among the elderly, the risk of dementia increases fourfold after an ischemic stroke. ${ }^{6,9}$

Studies have clearly shown that people with isolated cognitive deficits are at greater risk of having problems at work, have greater difficulty with dayto-day activities, are dependent on others and are poor drivers. ${ }^{1,10,11}$

However, certain subjects relating to $\mathrm{CF}$ remain controversial, including its correlation with obstructive carotid disease. For this reason, the present review was conducted with the object of analyzing the impact of carotid revascularization and the repercussions of which carotid revascularization technique is chosen (CEA vs. carotid artery stenting).

\section{METHOD}

The methodology employed was a bibliographic review, attempting to answer the following questions:

- Does carotid revascularization have an impact on cognitive function?

- Is there a difference between the two different intervention techniques (endarterectomy and carotid stenting)?

Articles were located by searching the PubMed electronic database. A retrospective search was run covering publications from 1951 to 2013 using the following keywords: carotid endarterectomy; carotid stenting; cognitive changes; cognitive function. Results were restricted to articles published in English.

Articles of interest identified by the initial search strategy were first independently assessed by two of the authors. In order to avoid the risk of excluding any studies that could be important to the review, a consensus meeting was held and then both reviewers chose all the titles they had identified as potentially relevant to the object of study, irrespective of whether or not an abstract was available. Once relevant titles had been selected, the full texts of the articles were acquired and each article was assessed against a protocol covering the following topics: study type, sample, type of intervention used, results observed. All longitudinal, prospective and retrospective articles, meta-analyses and review articles that met the criteria were included. Articles not yet published, comments and editorials, case reports and crosssectional studies were all excluded. Articles with very similar content were also excluded, giving priority to the first authors to publish on subject and/or those who described larger or more recent samples. The studies were chosen on the basis of the likelihood of their answering the research questions guiding this bibliographic review. On this basis, 189 articles were initially identified and 67 of them were selected and analyzed for this review.

\section{RESULTS}

\section{Mechanisms behind cognitive changes after carotid revascularization}

Carotid artery stenosis is recognized as a risk factor for cognitive impairment. ${ }^{6,12}$ However, the results of studies involving the effects of revascularization on cognition are controversial. ${ }^{6,13}$ If, on one hand, intervention for carotid stenosis should be beneficial because it restores cerebral blood flow, ${ }^{2,6}$ on the other hand, one review has suggested that carotid revascularization leads to a decline in cognitive function because of other mechanisms related to the patients operated and the technique employed. ${ }^{1}$

Patient-related factors include prior cerebral injury manifest as stroke, prior silent cortical infarct, prior white matter damage and morphology of atherosclerotic plaques. ${ }^{1}$

Factors related to the technique employed include microembolization, further cerebral microinfarcts, duration of cerebral hypoperfusion and incidence of systemic hypotension during revascularization. ${ }^{1}$ 


\section{Silent cerebral microinfarcts and cognitive decline}

The Rotterdam study showed that silent infarcts in healthy elderly people, identified by magnetic resonance imaging (MRI), doubled the risk of developing dementia and reduced CF over followup. ${ }^{1,14}$ These findings were confirmed by other important studies. ${ }^{15-17}$

On the other hand, surgical or catheter manipulation of the aorta during cardiac procedures can cause cerebral injuries secondary to microembolization. . $^{1,18,19}$ The postoperative cognitive decline observed in these patients has been related to these microemboli. ${ }^{1,20-22}$ Along the same lines, other studies have demonstrated that manipulation of the carotid artery during revascularization can cause atheroembolization with consequent silent cerebral microinfarcts. ${ }^{1,23-25}$

Transcranial Doppler (TCD) can differentiate gaseous from particulate microembolic material during revascularization procedures. ${ }^{26,27}$ Gaunt et al. ${ }^{28}$ showed that the occurrence of more than ten particulate microemboli during initial dissection for CEA is associated with cognitive decline. Differentiation of the more clinically relevant particulate emboli from gaseous emboli using multifrequency TCD monitoring techniques should therefore be encouraged. ${ }^{26,28,29}$

A study published in 2011 used TCD monitoring to identify approximately 15 microemboli (SD of 22) during CEA; 319.3 (SD of 110.3) during carotid artery stenting (CAS) with a distal filter, and 184.2 (SD of 110.5) during CAS using reverse flow as cerebral protection method. The differences between CEA and both CAS techniques were considered significant. However, the difference between the two CAS techniques was not significant, very probably because of the small number of patients studied (14, 14 and 5 , respectively). ${ }^{30}$

In line with these findings, another research group compared asymptomatic patients submitted to CEA or to CAS with distal filtering (20 and 23 patients, respectively) and found a significant difference, with detection of cerebral microinfarcts by diffusion MRI much more frequent when using CAS ( $21 \%$ vs. $0 \%) .{ }^{31}$ Roh et al. compared CEA to CAS, ${ }^{32}$ observing that both neurological events and new lesions seen on MRI were more common in the CAS group. Rapp et al. ${ }^{33}$ reported on a series of 48 patients submitted to 54 CAS procedures with excellent clinical results, but with a considerable number of new lesions on diffusion MRI. While these lesions are very often uncorrelated with clinical changes, studies have demonstrated that repeated embolic injuries have cumulative effects. ${ }^{31,34}$

Notwithstanding, the influence that these differences may have on the neurocognitive results of carotid revascularization has not yet been fully explained, since large-scale studies were focused on strokes. ${ }^{1}$ A study of heart surgery patients demonstrated that embolic events during operations were related to memory deficits. ${ }^{26,35}$ By extrapolation, this finding might also be of relevance to carotid revascularization patients.

\section{Hemodynamic changes and repercussions for cognitive function}

Carotid revascularization improves cerebral blood flow, which can translate into an improvement in CF. ${ }^{1,26,36-39}$ Borroni et al. ${ }^{39}$ identified a subset of their CEA patients who had moderate vascular dementia and showed that $60 \%$ of this subset enjoyed cognitive improvement after surgery. This potential benefit could be achieved for all patients, irrespective of revascularization technique.

However, all of the techniques involve transitory attenuation of cerebral blood flow, ${ }^{1}$ and some studies have related this to transitory or persistent cognitive deficits. ${ }^{1,26,38,40-44}$ Carotid endarterectomy is generally associated with longer periods of ipsilateral carotid flow privation (mean duration of 337 seconds) than CAS (mean duration of 26 seconds; $p<0.001$ ). ${ }^{43}$

A study with patients submitted to heart surgery demonstrated that hypoperfusion during the procedure was related to attention deficit. ${ }^{35}$ This finding is also of relevance to patients undergoing carotid revascularization procedures, since these operations also involve a certain degree of hypoperfusion.

Cerebral hypoperfusion is defined as cerebral blood flow below $30 \%$ of normal flow. ${ }^{23,26,44}$ The most widely used strategies intended to avoid hypoperfusion during CEA are either a selective shunt (guided by cerebral monitoring using continuous electroencephalogram, TCD or neurological examination) or a universal shunt. ${ }^{26,41,44-46}$ More recently, cerebral oximetry, bispectral index and evoked potentials are also being used for cerebral monitoring during surgery at some centers. ${ }^{24,47,48}$

Additionally, another event that can occur in relation to both types of revascularization procedure is systemic hypotension, defined as a drop in systemic systolic pressure of $>30 \mathrm{mmHg}$, compared with baseline, ${ }^{26,45}$ which is more frequent with CAS (more than $68 \%$ of patients), ${ }^{49-52}$ and is associated with elevated levels of biochemical markers (S100B) of glial injury. ${ }^{53}$ 
Although CAS involves shorter periods of blood flow privation, it appears to cause greater hemodynamic instability when compared with CEA. The combined impact of these competing factors has not yet been fully investigated. ${ }^{1}$

\section{Cognitive changes after carotid revascularization: endarterectomy vs. carotid angioplasty}

Systematic reviews conducted by Lunn et al. and Irvine et al. demonstrate the complete absence of consensus on cognitive outcomes after CEA. ${ }^{54,55}$ They found that 16 out of 28 studies analyzed demonstrated improved CF after CEA, but that the remaining 12 either did not detect improvements or even found evidence of a decline in $\mathrm{CF}$.

Heyer et al. compared the CF of 80 patients who underwent CEA with controls who had had orthopedic surgery. They found a decline in one out of four cognitive tests and when all test results were analyzed together, there was a significant decline in overall scores for the CEA group. This study was limited by follow-up that was short and incomplete. ${ }^{56}$

The first studies of which we are aware involving CAS emphasized its neurocognitive consequences, but CAS methodology evolved and now includes stent placement and the use of cerebral protection devices. ${ }^{1,57}$ The most common form of cerebral protection is placement of a filter in the distal internal carotid before conducting angioplasty of the carotid bifurcation and was developed to reduce microembolization, but the method is not able to completely eliminate the occurrence of this phenomenon. This fact has been explained by the lack of protection during instrumentation of the aortic arch and passage of the guide wire past the carotid lesion and by failure to capture all emboli after installing the filter. ${ }^{30,58,59}$ Proximal occlusion and reverse flow are other potential alternatives for these deficits, since both cerebral protection devices are installed before manipulation of the lesion and both involve stopping anterograde flow in the internal carotid. ${ }^{30}$

A study conducted in $2006^{60}$ of 40 patients submitted to CAS with a cerebral protection device used mini mental state examinations to test $\mathrm{CF}$, reported improvements after CAS, which is a trend that has also been observed by other authors. ${ }^{61}$ However, another group of researchers ${ }^{62}$ compared a group of 24 patients who underwent CAS with a control group of patients submitted to coronary angioplasty and concluded that CAS could be responsible for a moderate cognitive decline over the short term.
Analysis of studies that have compared one carotid revascularization technique with another revealed that there is still a great deal of controversy. ${ }^{6,31,63-67}$ Capoccia et al. conducted a non-randomized study in which they respected clinical and anatomic criteria to indicate either CEA (20 patients) or CAS (23 patients) and administered mini mental state examinations over the short and medium term to both groups, concluding that $\mathrm{CF}$ worsened in the second group only. The authors detected a positive relationship between this finding and a higher rate of lesions detected within 24 hours using diffusion magnetic resonance ( $0 \%$ versus $21 \%$, respectively). ${ }^{31}$

Feliziani et al. conducted a study including analysis of cognitive aspects of asymptomatic individuals submitted to carotid revascularization (24 patients operated using the CAS technique versus 22 patients using the CEA technique). They investigated three questions related to $\mathrm{CF}$, as follows: 1- To what extent does revascularization itself affect $\mathrm{CF}$, irrespective of the technique employed? 2- What is the behavior of $\mathrm{CF}$ over time ( 3 and 12 months after operating)? 3- Which is the best technique in terms of CF? They assessed CF in several different domains: memory; attention and executive functions; and constructive and visuospatial abilities. In relation to the first and third questions: there were no statistically significant results. In relation to the second question, the performance of patients who had undergone CAS deteriorated over time in constructive and visuospatial abilities. ${ }^{6}$

Lal et al. studied asymptomatic patients submitted to CEA (25 individuals) or CAS (21 individuals) and conducted tests of several domains of cognition during the immediate postoperative period and 4 to 6 months after the procedures. They concluded that there was cognitive improvement after both techniques and that there was no difference in overall test results between the two techniques. However, analysis of domain-specific scores showed that CEA resulted in a reduction in memory, while CAS patients exhibited worsened psychomotor velocity. ${ }^{63}$

In contrast, Takaiwa et al. studied 26 patients (15 operated with CAS and 11 operated by CEA) and concluded that although there was no statistical difference between the two techniques in terms of CF, there were improvements in the domains 'memory' and 'attention' after carotid revascularization and these improvements were sustained over time (12 months). ${ }^{64}$

Studies that have investigated this subject vary greatly in terms of the following aspects: the point in time at which tests are administered; use of specific 
tests; use of control groups; duration of postoperative follow-up period; number of patients studied; and severity of stenoses operated. ${ }^{1}$

\section{CONCLUSIONS}

The literature reviewed makes it clear that carotid stenoses are related to cognitive decline over time. There is still much controversy with relation to the impact carotid revascularization has on $\mathrm{CF}$. Microembolizations and hemodynamic fluctuations that can occur during carotid interventions contribute to worsening the performance of revascularized patients in cognitive tests. However, there is no consensus among the most up-to-date studies on this trend. There are high quality studies that have confirmed a reduction in cognitive performance, but many others have shown stability or even improvements in performance.

The majority of studies that compared endarterectomy to carotid stenting did not detect a difference between the two techniques in terms of overall cognitive outcome. Further studies are needed to investigate the impact of carotid revascularization on the several different domains of cognition.

\section{REFERENCES}

1. Lal BK. Cognitive function after carotid artery revascularization. Vasc Endovasc Surg. 2007;41(1):5-13. PMid:17277237. http:// dx.doi.org/10.1177/1538574406297253

2. Fisher C. Senile dementia - a new explanation of its causation. Arch Neurol. 1951;65:1-7.

3. Carrea R, Molins M, Murphy G. Surgery of spontaneous thrombosis of internal carotid in the neck; carotid-carotid anastomosis; case report and analysis of the literature on surgical cases. Medicina (B. Aires). 1955;15:20-9.

4. DeBakey ME. Successful carotid endarterectomy for cerebrovascular insufficiency. Nineteen-year follow-up. JAMA. 1975;233:1083-5. PMid:1174155. http://dx.doi.org/10.1001/ jama.1975.03260100053020

5. Eastcott $\mathrm{HH}$, Pickering GW, Rob CG. Reconstruction of internal carotid artery in a patient with intermittent attacks of hemiplegia. Lancet. 1954;267:994-6. http://dx.doi.org/10.1016/ S0140-6736(54)90544-9

6. Feliziani FT, Polidori MC, De Rango P, et al. Cognitive performance in elderly patients undergoing carotid endarterectomy or carotid artery stenting: a twelve-month follow-up study. Cerebrovasc Dis. 2010;30:244-51. PMid:20664257. http://dx.doi. org/10.1159/000319066

7. Seshadri S, Beiser A, Kelly-Hayes $M$, et al. The lifetime risk of stroke: estimates from the Framingham study. Stroke. 2006;37:345-50. PMid:16397184. http://dx.doi.org/10.1161/01. STR.0000199613.38911.b2

8. Hachinski V. The 2005 Thomas Willis lecture: stroke and vascular cognitive impairment - a transdisciplinary, translational and transactional approach. Stroke. 2007;38:1396. PMid:17347469. http://dx.doi.org/10.1161/01.STR.0000260101.08944.e9
9. Desmond DW, Moroney JT, Sano M, Stern Y. Incidence of dementia after ischemic stroke: results of a longitudinal study. Stroke. 2002;33:2254-60. PMid:12215596. http://dx.doi. org/10.1161/01.STR.0000028235.91778.95

10. Rao SM, Leo GJ, Ellington L, Nauertz T, Bernardin L, Unverzagt F. Cognitive dysfunction in multiple sclerosis. II. Impact on employment and social functioning. Neurology. 1991;41:692-6. PMid:1823781. http://dx.doi.org/10.1212/WNL.41.5.692

11. Chaytor N, Schmitter-Edgecombe M. The ecological validity of neuropsychological tests: a review of the literature on everyday cognitive skills. Neuropsychol Rev. 2003;13:181-97. PMid:15000225. http://dx.doi.org/10.1023/B:NERV.0000009483.91468.fb

12. Hachinski V, ladecola C, Petersen RC, et al. National Institute of Neurological Disorders and Stroke-Canadian Stroke Network vascular cognitive impairment harmonization standards. Stroke. 2006;37:2220-41. PMid:16917086. http://dx.doi.org/10.1161/01. STR.0000237236.88823.47

13. Rasmussen LS. Postoperative cognitive dysfunction: incidence and prevention. Best Pract Res Clin Anaesthesiol. 2006;20:31530. PMid:16850780. http://dx.doi.org/10.1016/j.bpa.2005.10.011

14. Vermeer SE, Prins ND, Den Heijer T, Hofman A, Koudstaal PJ, Breteler MMB. Silent brain infarcts and the risk of dementia and cognitive decline. N Engl J Med. 2003;348:1215-22. PMid:12660385. http://dx.doi.org/10.1056/NEJMoa022066

15. Mosley TH Jr, Knopman DS, Catellier DJ, et al. Cerebral MR findings and cognitive functioning: the Atherosclerosis Risk in Communities Study. Neurology. 2005;64:2056-62. PMid:15985571. http://dx.doi.org/10.1212/01.WNL.0000165985.97397.88

16. Longstreth WT Jr, Bernick C, Manolio TA, Bryan N, Jungreis CA, Price TR. Lacunar infarcts defined by magnetic resonance imaging of 3660 elderly people: the Cardiovascular Health Study. Arch Neurol. 1998;55:1217-25. http://dx.doi.org/10.1001/ archneur.55.9.1217

17. Capoccia L, Sbarigia E, Rizzo A, Mansour W, Speziale F. Silent stroke and cognitive decline in asymptomatic carotid stenosis revascularization. Vascular. 2012;20(4):181-7. PMid:22734086. http://dx.doi.org/10.1258/vasc.2011.oa0342

18. Braekken SK, Russell D, Brucher R, Abdelnoor M, Svennevig JL. Cerebral microembolic signals during cardiopulmonary bypass surgery. Frequency, time of occurrence, and association with patient and surgical characteristics. Stroke. 1997;28:1988-92. PMid:9341708. http://dx.doi.org/10.1161/01.STR.28.10.1988

19. Braekken SK, Endresen K, Russell D, Brucher R, Kjekshus J. Influence of guidewire and catheter type on the frequency of cerebral microembolic signals during left heart catheterization. Am J Cardiol. 1998;82:632-7. http://dx.doi.org/10.1016/ S0002-9149(98)00407-X

20. Braekken SK, Reinvang I, Russell D, Brucher R, Svennevig JL. Association between intraoperative cerebral microembolic signals and postoperative neuropsychological deficit: comparison between patients with cardiac valve replacement and patients with coronary artery bypass grafting. J Neurol Neurosurg Psychiatry. 1998;65:573-6. PMid:9771790. http://dx.doi. org/10.1136/jnnp.65.4.573

21. Sylivris S, Levi C, Matalanis G, et al. Pattern and significance of cerebral microemboli during coronary artery bypass grafting. Ann Thorac Surg. 1998;66:1674-8. http://dx.doi.org/10.1016/ S0003-4975(98)00891-1

22. Laza C, Popescu BO, Popa M, et al. Microemboli detection in patients with carotid artery stenting--a potential marker for future cognitive impairment? J Neurol Sci. 2013;326(1-2):96-9. PMid:23403326. http://dx.doi.org/10.1016/j.jns.2013.01.025 
23. Crawley F, Stygall J, Lunn S, Harrison M, Brown MM, Newman S. Comparison of microembolism detected by transcranial Doppler and neuropsychological sequelae of carotid surgery and percutaneous transluminal angioplasty. Stroke. 2000;31:1329-34. PMid:10835452. http://dx.doi.org/10.1161/01.STR.31.6.1329

24. Jordan WD Jr, Voellinger DC, Doblar DD, Plyushcheva NP, Fisher WS, McDowell HA. Microemboli detected by transcranial Doppler monitoring in patients during carotid angioplasty versus carotid endarterectomy. Cardiovasc Surg. 1999;7:33-8. http:// dx.doi.org/10.1016/S0967-2109(98)00097-0

25. Wolf O, Heider P, Heinz M, et al. Microembolic signals detected by transcranial doppler sonography during carotid endarterectomy and correlation with serial diffusionweighted imaging. Stroke. 2004;35:e373-5. PMid:15388901. http://dx.doi.org/10.1161/01. STR.0000143184.69343.ec

26. Ghogawala Z, Westerveld M, Amin-Hanjani S. Cognitive outcomes after carotid revascularization: the role of cerebral emboli and hypoperfusion. Neurosurg. 2008:385-95. PMid:18382316.

27. Ringelstein EB, Droste DW, Babikian VL, et al. Consensus on microembolus detection by TCD. International Consensus Group on Microembolus Detection. Stroke. 1998;29:725-9. PMid:9506619. http://dx.doi.org/10.1161/01.STR.29.3.725

28. Gaunt ME, Smith JL, Bell PR, Martin PJ, Naylor AR. Microembolism and hemodynamic changes in the brain during carotid endarterectomy. Stroke. 1994;25:2504-5. PMid:7974598. http:// dx.doi.org/10.1161/01.STR.25.12.2504

29. Chen $\mathrm{Cl}$, Iguchi Y, Garami Z, et al. Analysis of emboli during carotid stenting with distal protection device. Cerebrovasc Dis. 2006;21:223-8. PMid:16446534. http://dx.doi. org/10.1159/000091218

30. Gupta N, Corriere MA, Dodson TF, et al. The incidence of microemboli to the brain is less with endarterectomy than percutaneous revascularization with distal filters or flow reversal. J Vasc Surg. 2011;53:316-22. PMid:21129899. http://dx.doi. org/10.1016/j.jvs.2010.08.063

31. Capoccia L, Speziale F, Gazzetti M, et al. Comparative study on carotid revascularization(endarterectomy vs stenting) using markers of cellular brain injury, neuropychometric tests, and diffusion-weighted magnetic resonance imaging. J Vasc Surg. 2010;51:584-92. PMid:20045614. http://dx.doi.org/10.1016/j. jvs.2009.10.079

32. Roh HG, Byun HS, Ryoo JW, et al. Prospective analysis of cerebral infarction after carotid endarterectomy and carotid artery stent placement by using diffusion-weighted imaging. Am J Neuroradiol. 2005;26:376-84. PMid:15709140.

33. Rapp JH, Wakil L, Sawhney R, et al. Subclinical embolization after carotid artery stenting:new lesions on diffusion-weighted magnetic resonance imaging occur postprocedure. J Vasc Surg. 2007;45:867-74. PMid:17376643. http://dx.doi.org/10.1016/j. jvs.2006.12.058

34. Hauth EA, Jansen C, Drescher R, et al. MR and clinical follow-up of diffusion-weighted cerebral lesions after carotid artery stenting. Am J Neuroradiol. 2005;26:2336-4. PMid:16219842.

35. Fearn SJ, Pole R, Wesnes K, Faragher EB, Hooper TL, McCollum $\mathrm{CN}$. Cerebral injury during cardiopulmonary bypass: Emboli impair memory. J Thorac Cardiovasc Surg. 2001;121:1150-60. PMid:11385383. http://dx.doi.org/10.1067/mtc.2001.114099

36. Sasoh M, Ogasawara K, Kuroda K, et al. Effects of EC-IC bypass surgery on cognitive impairment in patients with hemodynamic cerebral ischemia. Surg Neurol. 2003;59:455-60; discussion 460-453.
37. Younkin D, Hungerbuhler JP, O'Connor M, et al. Superficial temporal-middle cerebral artery anastomosis: effects on vascular, neurologic, and neuropsychological functions. Neurology. 1985;35:462-9. PMid:3982632. http://dx.doi.org/10.1212/ WNL.35.4.462

38. Marshall RS, Lazar RM, Pile-Spellman J, et al. Recovery of brain function during induced cerebral hypoperfusion. Brain. 2001;124:1208-17. PMid:11353736. http://dx.doi.org/10.1093/ brain/124.6.1208

39. Borroni B, Tiberio G, Bonardelli $S$, et al. Is mild vascular cognitive impairment reversible? Evidence from a study on the effect of carotid endarterectomy. Neurol Res. 2004;26:594-7. PMid:15265280. http://dx.doi.org/10.1179/016164104225016245

40. Costin M, Rampersad A, Solomon RA, Connolly ES, Heyer EJ. Cerebral injury predicted by transcranial Doppler ultrasonography but not electroencephalography during carotid endarterectomy. J Neurosurg Anesthesiol. 2002;14:28792. PMid:12357085 PMCid:PMC2435244. http://dx.doi. org/10.1097/00008506-200210000-00003

41. Heyer EJ, Adams DC, Solomon RA, et al. Neuropsychometric changes in patients after carotid endarterectomy. Stroke. 1998;29:1110-5. PMid:9626280 PMCid:PMC2435204. http:// dx.doi.org/10.1161/01.STR.29.6.1110

42. Ogasawara $K$, Inoue $T$, Kobayashi $M$, et al. Cognitive impairment associated with intraoperative and postoperative hypoperfusion without neurologic deficits in a patient undergoing carotid endarterectomy. Surg Neurol. 2006;65:577-81. PMid:16720178. http://dx.doi.org/10.1016/j.surneu.2005.07.011

43. Lund C, Hol PK, Lundblad R, et al. Comparison of cerebral embolization during off-pump and on-pump coronary artery bypass surgery. Ann Thorac Surg. 2003;76:765-70; discussion 770 . http://dx.doi.org/10.1016/S0003-4975(03)00679-9

44. Sundt TM, Sharbrough FW, Piepgras DG, Kearns TP, Messick JM, O'Fallon WM. Correlation of cerebral blood flow and electroencephalographic changes during carotid endarterectomy: With results of surgery and hemodynamics of cerebral ischemia. Mayo Clin Proc. 1981;56:533-43. PMid:7266064.

45. HalseyJH. Risks and benefits of shunting in carotid endarterectomy. The International Transcranial Doppler Collaborators. Stroke. 1992;23:1583-7. http://dx.doi.org/10.1161/01.STR.23.11.1583

46. Lawrence PF, Alves JC, Jicha D, Bhirangi K, Dobrin PB. Incidence, timing, and causes of cerebral ischemia during carotid endarterectomy with regional anesthesia.J Vasc Surg. 1998;27:32937. http://dx.doi.org/10.1016/S0741-5214(98)70363-5

47. Calderon-Arnulphi M, Alaraj A, Amin-Hanjani S, et al. Detection of cerebral ischemia in neurovascular surgery using quantitative frequency-domain near-infrared spectroscopy. J Neurosurg. 2007;106:283-90. PMid:17410713. http://dx.doi.org/10.3171/ jns.2007.106.2.283

48. White PF. Use of cerebral monitoring during anaesthesia. Effect on recovery profile. Best Pract Res Clin Anaesthesiol. 2006;20:1819. PMid:16634424. http://dx.doi.org/10.1016/j.bpa.2005.08.001

49. Mendelsohn FO, Weissman NJ, Lederman RJ, et al. Acute hemodynamic changes during carotid artery stenting. Am J Cardiol. 1998;82:1077-81. http://dx.doi.org/10.1016/ S0002-9149(98)00562-1

50. Trocciola SM, Chaer RA, Lin SC, et al. Analysis of parameters associated with hypotension requiring vasopressor support after carotid angioplasty and stenting. J Vasc Surg. 2006;43:714. PMid:16616226. http://dx.doi.org/10.1016/j.jvs.2005.12.008

51. Gupta R, Abou-Chebl A, Bajzer CT, Schumacher HC, Yadav JS Rate, predictors, and consequences of hemodynamic depression 
after carotid artery stenting. J Am Coll Cardiol. 2006;47:1538-43. PMid:16630988. http://dx.doi.org/10.1016/j.jacc.2005.08.079

52. Park B, Shapiro D, Dahn M, Arici M. Carotid artery angioplasty with stenting and postprocedure hypotension. Am J Surg. 2005;190:691-5. PMid:16226941. http://dx.doi.org/10.1016/j. amjsurg.2005.07.004

53. Connolly ES, Winfree C), Rampersad A, et al. Serum S100B protein levels are correlated with subclinical neurocognitive declines after carotid endarterectomy. Neurosurg. 2001;49:1076-83.

54. Lunn S, Crawley F, Harrison MJ, Brown MM, Newman SP. Impact of carotid endarterectomy upon cognitive functioning. A systematic review of the literature. Cerebrovasc Dis. 1999;9:74-81. PMid:9973649. http://dx.doi.org/10.1159/000015901

55. Irvine CD, Gardner FV, Davies AH, Lamont PM. Cognitive testing in patients undergoing carotid endarterectomy. Eur J Vasc Endovasc Surg. 1998;15:195-204. http://dx.doi.org/10.1016/ S1078-5884(98)80176-7

56. Heyer EJ, Sharma R, Rampersad A, et al. A controlled prospective study of neuropsychological dysfunction following carotid endarterectomy. Arch Neurol. 2002;59:217-22. PMid:11843692 PMCid:PMC2435245. http://dx.doi.org/10.1001/archneur.59.2.217

57. Hobson RW 2nd. Update on the Carotid Revascularization Endarterectomy versus Stent Trial (CREST) protocol. J Am Coll Surg. 2002;194(1 suppl):S9-14. http://dx.doi.org/10.1016/ S1072-7515(01)01078-X

58. Xu G, Liu X, Meyer JS, Yin Q, Zhang R. Cognitive performance after carotid angioplasty and stenting with brain protection devices. Neurol Res. 2007;29:251-5. PMid:17178010. http://dx.doi. org/10.1179/016164107X159216

59. No authors listed. Endovascular versus surgical treatment in patients with carotid stenosis in the Carotid and Vertebral Artery Transluminal Angioplasty Study (CAVATAS):a randomised trial. Lancet. 2001;357:1729-37. http://dx.doi.org/10.1016/ S0140-6736(00)04893-5

60. Grunwald I, Suppurian T, Struffert T, Falkai P, Krick C, Politi M. Cognitive Changes after Carotid Artery Stenting. Neuroradiology. 2006;48:319-23. PMid:16703361. http://dx.doi.org/10.1007/ s00234-006-0064-5

61. Mlekusch W, Mlekusch I, Haumer M, Kopp CW, Lehrner J, Ahmadi R et al. Improvement of neurocognitive function after protected carotid artery stenting. Catheter Cardiovasc Interv. 2008;71(1):114-9. PMid:18098213. http://dx.doi.org/10.1002/ ccd. 21407

62. Gaudet JG, Meyers PM, McKinsey JF, et al. Incidence of moderate to severe cognitive dysfunction in patients treated with carotid artery stenting. Neurosurgery. 2009;65(2):325-9; discussion 329-30. PMid:19625912 PMCid:PMC2716040. http://dx.doi. org/10.1227/01.NEU.0000349920.69637.78

63. Lal BK, Younes M, Cruz G, Kapadia I, Jamil Z, Pappas PJ. Cognitive changes after surgery vs stenting for carotid artery stenosis. J Vasc Surg. 2011;54(3):691-8. PMid:21700413. http://dx.doi. org/10.1016/j.jvs.2011.03.253
64. Takaiwa A, Hayashi N, Kuwayama N, Akioka N, Kubo M, Endo S. Changes in cognitive function during the 1-year period following endarterectomy and stenting of patients with high-grade carotid artery stenosis. Acta Neurochir. 2009;151:1593-1600. PMid:19533017. http://dx.doi.org/10.1007/s00701-009-0420-4

65. Zhou W, Hitchner E, Gillis K, et al. Prospective neurocognitive evaluation of patients undergoing carotid interventions. J Vasc Surg. 2012;56(6):1571-8. PMid:22889720 PMCid:PMC3508143. http://dx.doi.org/10.1016/j.jvs.2012.05.092

66. Altinbas A, van Zandvoort MJ, van den Berg E, et al. Cognition after carotid endarterectomy or stenting: a randomized comparison. Neurology. 2011;77(11):1084-90. PMid:21880992. http://dx.doi.org/10.1212/WNL.0b013e31822e55b9

67. Witt K, Börsch K, Daniels C, et al. Neuropsychological consequences of endarterectomy and endovascular angioplasty with stent placement for treatment of symptomatic carotid stenosis: prospective randomised study. J Neurol. 2007;254(11):1524-32. PMid:17657403. http://dx.doi.org/10.1007/s00415-007-0576-x

Correspondence Germano da Paz Oliveira Rua José Olímpio de Melo, 3426, apto. 102 - Ilhotas CEP 64014-063 - Teresina, (PI), Brazi Tel.: +55 (86) 9982-0901 E-mail: germanooliveira@hotmail.com

Author information

GPO é Cirurgião Vascular, Mestre em Ciências pela Faculdade de Ciências Médicas (FCM), Universidade Estadual de Campinas (UNICAMP)

ATG é Professora Livre-Docente da Disciplina de Moléstias Vasculares Periféricas do Departamento de Cirurgia da Faculdade de Ciências Médicas (FCM), Universidade Estadual de Campinas (UNICAMP). IBB é Graduando de Medicina, Universidade Federal do Piauí (UFPI). IMTL é Graduanda de Medicina, Universidade Federal do Piau (UFPI)

SCB é Graduando de Medicina, Centro Universitário UniNovafap. FC é Professor Titular do Departamento de Neurologia da Faculdade de Ciências Médicas (FCM), Universidade Estadual de Campinas (UNICAMP)

Author contributions Conception and design: GPO, ATC, FC Analysis and interpretation: GPO, ATG, IBB, JMTL, SCB, FC Data collection: GPO, ATG, IBB, JMTL, SCB, FC Writing the article: GPO, ATG, IBB, JMTL, SCB, FC Critical revision of the article: GPO, ATG and FC Final approval of the article*: GPO, ATG, IBB, JMTL, SCB, FC Statistical analysis: GPO Overall responsibility: GPO, ATG, FC Obtained funding: None

*All authors have read and approved of the final version of the article submitted to J Vasc Bras 